\title{
TEORIE JĘZYKA A PLURALIZM WARTOŚCI W KONTEKŚCIE TEORII WYKŁADNI PRAWA
}

I. Każde teoretyczne ujęcie wykładni prawa (w szczególności - każda normatywna koncepcja wykładni), jak również każda dostatecznie wykształcona praktyka interpretacyjna przyjmuje, często jedynie implicite, czy też nawet w sposób nieuświadomiony, określone filozoficzne założenia dotyczące tego, czym jest język, a także pewne aksjologiczne założenia dotyczące dobrego państwa i społeczeństwa, określające m.in. stosunek do faktu pluralizmu wartości. Mogłoby się wydawać, że ze względu na inny przedmiot założenia te nie są ze sobą powiązane (dotyczą one czegoś innego). Celem niniejszego artykułu jest jednak wskazanie, że chociaż założenia te nie są ze sobą bezpośrednio powiązane (dotyczą przecież innych sfer rzeczywistości), to jednak występuja między nimi pewne relacje, które powoduja, że przy rozstrzyganiu teoretycznych zagadnień związanych z wykładnią prawa przyjęcie określonych założeń dotyczących języka łatwiej pogodzić można z określonymi założeniami dotyczącymi pozytywnego bądź negatywnego stosunku do faktu pluralizmu wartości.

II. Ze względu na cel opracowania należy w pierwszej kolejności ogólnie scharakteryzować dwie alternatywne ogólne teorie komunikacji za pośrednictwem języka, a także związki między nimi a sposobem rozstrzygania teoretycznych zagadnień z zakresu wykładni prawa.

Poniżej zostaną scharakteryzowane dwie modelowe teorie przedstawiające określone wizje języka i komunikacji za jego pomoca, na które składać się będa określone założenia z zakresu filozofii języka. Pierwszą z nich będzie wizja strukturalistyczna (model strukturalistyczny), drugą zaś - nominalistyczna (model nominalistyczny). Rozróżnienie tych dwóch wizji będzie miało charakter pewnego uproszczenia i typologii, można bowiem wskazać wiele rozwiązań pośrednich (polegających na akceptacji niektórych założeń składających się na pierwszą z tych wizji, niektórych zaś innych należących do drugiej z nich). Na potrzeby niniejszego opracowania użyteczne jest jednak wskazanie pewnych wzorcowych i przeciwstawnych względem siebie rozwiązań (typów poglądów), aby lepiej widoczne były podstawowe kontrowersje.

Ze względu na ograniczoną objętość opracowania odpowiednie dwie wizje (modele) języka zostaną scharakteryzowane skrótowo (można powiedzieć „hasłowo”) za pomocą wyszczególnienia podstawowych składających się na 
nie założeń. Założenia te mają charakter bardzo ogólny, mogą być one różnie doprecyzowane i w efekcie mogą występować w bardziej „umiarkowanej” bądź bardziej „radykalnej” wersji. Warto też dodać, że nie należy utożsamiać omawianych wizji z jakimiś konkretnymi filozoficzno-teoretycznymi poglądami na język. Będą to raczej pewne typy poglądów, które mogą występować w ramach różnych orientacji teoretycznych i filozoficznych. Zaznaczyć również należy, że liczba wymienionych założeń może zostać zapewne zwiększona, jednakże na potrzeby niniejszego artykułu przyjęty ich katalog wydaje się wystarczający. Warto także dodać, że pierwszy ze sposobów pojmowania języka i komunikacji za jego pomoca został określony jako „strukturalistyczny” nie tyle ze względu na jego związki ze strukturalizmem jako orientacja teoretyczną w językoznawstwie (choć niewątpliwie związki te zachodza), ile raczej ze względu na sposób pojmowania języka jako pewnej abstrakcyjnej struktury. Druga zaś z wizji języka została określona mianem „nominalistycznej”, aby podkreślić jej zwiąki z pojęciem nominalizmu lingwistycznego ${ }^{1}$.

Można powiedzieć, że na strukturalistyczny sposób pojmowania języka składają się następujące założenia: 1) odróżnienie systemu językowego od posługiwania się językiem, 2) przyjęcie regulatywnego charakteru systemu językowego (struktury językowej) względem praktyki posługiwania się językiem, 3) dążenie do wyraźnego odróżnienia semantyki od pragmatyki, 4) założenie istnienia i możliwości wyodrębnienia w każdej (a co najmniej w znacznej większości) wypowiedzi (użyć języka) jej znaczenia syntaktyczno-semantycznego (systemowego); 5) uznanie, że do właściwego zrozumienia wypowiedzi językowej konieczne jest uprzednie ustalenie jej znaczenia systemowego (syntaktyczno-semantycznego), 6) uznanie, że syntaktyczno-semantyczne znaczenie wypowiedzi językowej odgrywa w procesie jej rozumienia rolę w jakiś sposób ograniczająca.

Z kolei na nominalistyczną wizję języka składają się następujące założenia: 1) uznanie, że nie istnieje abstrakcyjny system językowy, język zaś sprowadza się w zasadzie do posługiwania się nim (używania wypowiedzi językowych); 2) odrzucenie regulatywnego charakteru systemu językowego (struktury językowej) względem praktyki posługiwania się językiem; 3) rezygnacja z odróżniania (czy też - wyraźnego odróżniania) semantyki od pragmatyki; 4) rezygnacja z przyjmowania istnienia (i możliwości wyodrębnienia) systemowego znaczenia wypowiedzi językowej; 5) odrzucenie konieczności uprzedniego ustalania (czy też ustalania w ogóle) znaczenia syntaktyczno-semantycznego dla prawidłowego zrozumienia wypowiedzi językowej 6) odrzucenie ograniczającej roli reguł syntaktycznych i semantycznych w procesie rozumienia wypowiedzi językowej.

\footnotetext{
${ }^{1}$ Nominalizm lingwistyczny stanowi jedno z podstawowych filozoficznych założeń neopragmatyzmu i poststrukturalizmu. Pojęcie nominalizmu lingwistycznego szczegółowo analizuje J. Kmita. Zob. na ten temat idem, Wymykanie się uniwersaliom, Warszawa 2000, s. 60-63, 145 i n. Nominalizm lingwistyczny stanowi podstawę różnych koncepcji interpretacji, a szczególnie wyraźnie obecny jest w koncepcji R. Rorty'ego. Na temat tejże zob. w szczególności R. Rorty, The Pragmatists's Progress, w: S. Collini (red.), Interpretation and Overinterpretation, Cambridge 1992, s. 89-108.
} 
Można powiedzieć, że podstawowa różnica (której konsekwencją są pozostałe różnice) między ujęciem strukturalistycznym a ujęciem nominalistycznym ma charakter ontologiczny. W świetle modelu strukturalistycznego istnieją dwa odrębne byty - abstrakcyjny system językowy oraz konkretne akty użycia wypowiedzi językowych. Komunikacja (przekazywanie treści znaczeniowych w drodze użycia wypowiedzi językowych) możliwa jest dzięki istnieniu abstrakcyjnej struktury, systemu językowego „oddzielonego” od reszty rzeczywistości, który określa prawidłowość syntaktyczną i znaczenie form językowych. Język jako system ma charakter przede wszystkim syntaktyczno-semantyczny, sytuacje zaś, w których używa się konkretnych form językowych znajdują się w zasadzie poza granicą tego systemu, choć czasami włącza się do niego również reguły pragmatyczne, jeżeli w sposób abstrakcyjny określają charakterystykę sytuacji, w których użycie określonej formuły językowej jest pragmatycznie właściwe. System językowy pozwala nie tylko na adekwatny opis i wyjaśnienie komunikacji za pomoca języka naturalnego, lecz także regulowanie praktyki językowej. Chociaż ostatecznie ustalone znaczenie wypowiedzi może niekiedy odbiegać od jej znaczenia ustalonego na podstawie reguł syntaktycznych i semantycznych, to jednak nie może ono odbiegać od niego w dowolnym stopniu. Innymi słowy, reguły syntaktyczne i semantyczne w jakimś stopniu ograniczają swobodę interpretatora.

$\mathrm{Z}$ kolei istotę modelu nominalistycznego najlepiej oddaje następujacca wypowiedź Donalda Davidsona: „[...] jeżeli język miałby być czymś, za co biora go przeważnie filozofowie i lingwiści, to nie ma języka. Nie ma go jako rzeczy, której trzeba się uczyć, opanować ją i cierpliwie znosić"2. Nawiązując do pojęcia nominalizmu lingwistycznego (zob. przyp. 2), można powiedzieć, że język jest w takim ujęciu agregatem aktów mówienia. Między tymi aktami mówienia (i sytuacjami, w których są one dokonywane) zachodzą różnorodne związki trudne do ścisłego skodyfikowania. Komunikacja językowa jest możliwa, z reguły bowiem interlokutorzy podzielają w jakimśs zakresie wiedzę o dotychczasowych sytuacjach użycia określonych formuł językowych, co w efekcie pozwala im na wzajemne zrozumienie (pominąć tutaj można inne założenia, które muszą oni o sobie przyjmować), wskazana jednak wiedza bardzo daleka jest od uporządkowanego systemu w sensie strukturalistycznym. Przy takim ujęciu język ma charakter przede wszystkim pragmatyczny, semantyka i syntaktyka są tylko pomocniczymi hipostazami, które mogą się przydać w procesie komunikacji językowej, ale nie muszą. Język pojmowany jest nie jako system lub struktura, lecz jako agregat zdarzeń, ewentualnie pewien proces ${ }^{3}$. Jakiekolwiek ograniczenia w rozumieniu wypowiedzi językowych, jeżeli w ogóle istnieja, to nie pochodzą od abstrakcyjnych, systemowych reguł syntaktycznych

2 D. Davidson, A Nice Derangement of Epitaphs, w: Truth and Interpretation. Perspectives on the Philosophy of Donald Davidson, red. E. LePore, New York 1986, s. 446.

${ }^{3}$ Pojmowanie języka jako pewnego procesu proponuje D. Zielińska. Zob. eadem, Proceduralny model języka. Językoznawstwo z pozycji teorii modeli nauk empirycznych, Kraków 2007, s. 57 i n. Nie jest to jednak propozycja czysto nominalistyczna, a wydaje się raczej pewnym połączeniem nominalizmu i strukturalizmu. 
i semantycznych. Źródłem tych ograniczeń będą raczej „przygodne” okoliczności związane z różnorodnymi faktami towarzyszącymi konkretnemu użyciu wypowiedzi. Ustalanie pewnej fikcji, jaka jest syntaktyczno-semantyczne znaczenie wypowiedzi językowej, może być z jakichś powodów interesujące, ale nie może w żaden sposób ograniczać interpretatora.

III. Każda praktyka interpretacji prawa, jak również każda koncepcja wykładni prawa (w szczególności koncepcja normatywna) musi zakładać, choćby nawet $\mathrm{w}$ sposób nieuświadomiony, pewną wizję języka i sposobu komunikacji za jego pomoca, co jest konsekwencją dość oczywistego faktu, że przedmiotem interpretacji prawa są właśnie wypowiedzi językowe. Z punktu widzenia niniejszego opracowania istotne jest to, że przyjęcie określonego stanowiska w kwestii relacji wykładni językowej do pozajęzykowej (przede wszystkim funkcjonalnej) zakłada przyjęcie, choćby w sposób nieuświadomiony, określonych założeń dotyczących języka i komunikacji za jego pomocą. Warto dodać, że chodzi tu o stanowisko generalne przyjmowane w określonej koncepcji wykładni, ewentualnie obecne implicite w praktyce interpretacyjnej określonej wspólnoty. Natomiast poza zakresem zainteresowania niniejszego opracowania pozostają sytuacje polegające na tym, że określony indywidualny interpretator przyjmuje ad hoc takie czy inne stanowisko w zależności od sytuacji interpretacyjnej, w jakiej się znajduje.

Pojmowanie wykładni językowej jako odwoływania się do syntaktycznych i semantycznych reguł systemu językowego (języka prawnego, prawniczego, a także powszechnego ${ }^{4}$ ), a także do reguł uwzględniających kontekst językowy, zakłada przyjęcie ogólnej strukturalistycznej wizji języka. W takim ujęciu należy odróżniać wykładnię językową od wykładni pozajęzykowej (w szczególności funkcjonalnej), która polega na odwołaniu się przy wykładni do czegoś innego niż syntaktyczne i semantyczne reguły systemu językowego, do czegoś, co mieści się w ramach kontekstu pragmatycznego wypowiedzi językowych zawartych w tekście prawnym (przede wszystkim kontekstu funkcjonalnego, na który składają się społecznie akceptowane wartości). Przy takim ujęciu istnieje konieczność dokonania wykładni językowej w pierwszej kolejności, a ponadto wyniki wykładni językowej odgrywaja w procesie interpretacji rolę ograniczająca, w taki czy inny sposób, swobodę interpretatora.

Z kolei w świetle nominalistycznej wizji języka pojawią się trzy możliwości pojmowania relacji wykładni językowej do pozajęzykowej. Po pierwsze, można odrzucić samo pojęcie wykładni językowej (jako odwołania się do systemu językowego) i uznać, że każda wykładnia jest w istocie pozajęzykowa (pozajęzykowa w relacji do strukturalistycznego rozumienia języka). Po drugie, można odrzucić pojęcie wykładni pozajęzykowej i uznać, że każda wykładnia jest w zasadzie językowa (przy przyjęciu nominalistycznego pojmowania języka). Po trzecie wreszcie, co wydaje się najlepiej odpowiadać ujęciu nominalistycz-

\footnotetext{
${ }^{4}$ Można w tym miejscu przyjąć, że szczególnego typu regułą semantyczną języka prawnego jest reguła mówiąca o quasi-idiomatyczności wyrażeń tego języka. O quasi-idiomatyczności wyrażeń tekstu prawnego zob. M. Zieliński, Wyktadnia prawa. Zasady, reguty, wskazówki, wyd. 6, Warszawa 2012, s. 99-107.
} 
nemu, można odrzucić samo rozróżnienie „językowa-pozajęzykowa” jako bezpodstawne.

Niezależnie od wyboru którejś ze wskazanych konwencji pojęciowo-terminologicznych, przy założeniu ujęcia nominalistycznego nie ma konieczności uprzedniego odwoływania się w trakcie wykładni do syntaktyczno-semantycznych reguł systemu językowego, a ponadto syntaktyczno-semantyczne reguły systemu językowego nie mogą odgrywać w procesie wykładni roli w jakikolwiek sposób ograniczającej interpretatora (wynik ich zastosowania może być czasami w taki czy inny sposób przydatny do rozstrzygnięcia problemu interpretacyjnego, ale nie łączą się z nim żadne normatywne konsekwencje).

Elementy zarówno ujęcia strukturalistycznego, jak i nominalistycznego widoczne są w wielu poglądach na wykładnię i nie jest bynajmniej celem niniejszego artykułu odnajdywanie tych elementów w ujęciach poszczególnych autorów. Istotne jest raczej to, co może stanowić podstawę wyboru któregoś ujęcia.

W tym miejscu należy przywołać pewne istotne założenie przyjmowane w niniejszym opracowaniu, które można określić mianem pluralizmu teoretycznego w odniesieniu do języka i interpretacji ${ }^{5}$. Polega ono na dopuszczeniu i uznaniu autonomiczności określonych sfer kultury i problemów związanych z interpretacją wypowiedzi językowych wytworzonych w ich ramach. W świetle takiego założenia realizowanie autonomicznych wartości określonych sfer kultury może wymuszać zupełnie odmienną teoretycznie wizję funkcjonowania języka. Zgodnie z takim założeniem nie ma więc ,języka w ogóle”, są natomiast określone teoretyczne wizje języka przyjmowane w poszczególnych sferach określonych kultur dla realizacji ich autonomicznych wartości. Uznanie trafności którejśs ze wskazanych (w punkcie II) wizji języka nie jest więc w świetle wskazanego założenia kwestia „faktycznego stanu rzeczy”, czy też uchwycenia jakiejśs obiektywnej i uniwersalnej istoty języka.

Rozstrzygnięcie o trafności i uniwersalności określonej wizji języka we wszystkich sferach kultury nie jest w zasadzie możliwe empirycznie lub teoretycznie, wizje te bowiem mają charakter „głębokich” filozoficznych założeń warunkujących samo badanie języka. W związku z tym wydaje się raczej, że dobra podstawą do wyboru określonej wizji języka jest jej spójność z innymi założeniami filozoficznymi (np. aksjologicznymi) przyjmowanymi (czy też postulowanymi do przyjęcia) w ramach określonej sfery kultury, a także z rekonstrukcją określonej praktyki interpretacyjnej.

Jeśli powyższe odniesie się do sfery związanej z interpretacją prawa, dodać należy, że w niniejszym opracowaniu przyjmuje się również, iż jednym z czynników wpływajacych na wybór określonej wizji języka na potrzeby wykładni powinien być także postulat intersubiektywności czynności interpretacyjnych i ich wyników. Przez intersubiektywność (intersubiektywną kontrolowalność) czynności interpretacyjnych i ich wyników rozumie się tutaj możliwość jednoznacznego ustalenia, przy odwołaniu się do „zewnętrznych” wobec inter-

${ }^{5} \mathrm{Na}$ temat założenia pluralizmu teoretycznego w odniesieniu do języka i interpretacji zob. O. Bogucki, O sposobach pojmowania twórczego charakteru interpretacji, „Archiwum Filozofii Prawa i Filozofii Społecznej” 2013, nr 1, s. 27. 
pretatora kryteriów, czy określona czynność została dokonana prawidłowo (i w związku z tym, czy prawidłowy jest jej wynik) ${ }^{6}$.

Przyjęcie założenia pluralizmu teoretycznego w odniesieniu do języka i interpretacji oraz postulat intersubiektywności czynności interpretacyjnych (i ich wyników) sprawiaja, że w dalszej części opracowania należy się zastanowić, jakie zależności istnieją między przyjęciem określonej wizji języka a określonymi aksjologicznymi stanowiskami dotyczącymi faktu pluralizmu wartości.

IV. Najlepszym wprowadzeniem do rozważań zawartych w niniejszym punkcie będzie sformułowanie następującego okresu warunkowego (a więc zdania o strukturze ,jeżeli ..., to ...”). Jeżeli wyobrazić sobie organiczną wspólnotę o charakterze monistycznym, całkowicie (bądź w przybliżeniu) homogeniczna aksjologicznie, zorganizowaną na bazie jednej koncepcji dobra (jednego systemu wartości), określającej wyraźnie i szczegółowo dążenia w sferze publicznej i prywatnej, to w takiej wspólnocie kontekst pozajęzykowy wykładni prawa (które tworzy się w ramach tejże wspólnoty) byłby tak dobrze określony, że z punktu widzenia postulatu intersubiektywności wyników wykładni odwołanie się do tego kontekstu pozajęzykowego z powodzeniem zastapić by mogło odwołanie się do syntaktycznych i semantycznych reguł systemu językowego.

W takiej sytuacji wykładnia językowa miałaby zdecydowanie drugorzędne znaczenie. Państwo i prawo tworzone w ramach takiej społeczności oparte by były na tak szczegółowych i jednoznacznych podstawach aksjologicznych, że wykładnia językowa stanowić by mogła jedynie potwierdzenie wykładni pozajęzykowej, ewentualnie rozstrzygać by mogła występujące (raczej rzadko) niejasności tego kontekstu. Nie mogłaby natomiast stanowić podstawy do odrzucenia jednoznacznego wyniku wykładni funkcjonalnej (czy ogólniej pozajęzykowej). Można więc powiedzieć, że z wizją tego rodzaju wspólnoty dobrze współgra nominalistyczna wizja języka (przy jednoczesnym założeniu oczywiście postulatu intersubiektywności wyników wykładni).

Nie budzi chyba żadnych wątpliwości to, że współczesne społeczeństwa zachodnich demokracji nie mają charakteru opisanej wyżej wspólnoty. Wspólnota taka stanowi niekiedy przedmiot pewnego rodzaju „nostalgicznej” tęsknoty w ramach poglądów komunitarystycznych, bez wątpienia nie mamy z nia jednak do czynienia w obecnej rzeczywistości społecznej. Wątpliwe wydaje się również to, czy (i ewentualnie kiedy) wspólnota taka istniała w przeszłości. Współcześnie w społeczeństwach zachodnich demokracji, w tym również w Polsce (choć w nieco mniejszym stopniu), niezaprzeczalnym faktem (mającym również swój wyraz w treści regulacji prawnych) jest pluralizm wartości rozumiany jako współegzystowanie różnych systemów wartości (różniące się pojmowaniem poszczególnych wartości, a także ich hierarchia), koncepcji „dobrego życia” czy też „dobrego społeczeństwa”. Warto tutaj wyraźnie zazna-

\footnotetext{
${ }^{6}$ Można więc powiedzieć, że zgodnie z postulatem intersubiektywności będzie się dążyć do takiego formułowania dyrektyw wykładni, aby w możliwie największym stopniu ograniczyć metodologiczną twórczość wykładni i uzyskać zdeterminowanie jej wyniku, choć nigdy nie jest to możliwe do uzyskania w pełni (więcej na ten temat zob. ibidem, s. 21 i n.).
} 
czyć, że w niniejszym opracowaniu chodzi o pluralizm jako pewien społeczno-polityczny fakt, nie zaś o jedno ze stanowisk w filozofii moralności ${ }^{7}$. Fakt ten, w połączeniu z odczuwana potrzebą zapewnienia również pewnej wspólnotowej podstawy funkcjonowania społeczeństwa, jest źródłem intensywnych debat $\mathrm{w}$ ramach filozofii polityki oraz filozofii moralności, które to debaty przekładają się na zróżnicowany stosunek wobec wskazanego faktu. Nie ma $\mathrm{w}$ niniejszym opracowaniu miejsca na szersze omawianie tej problematyki, jednak należy zarysować kilka typów stanowisk w tym zakresie ${ }^{8}$.

Po pierwsze, można mówić o wyraźnie „wrogim” (zdecydowanie negatywnym) stosunku do pluralizmu. Pluralizm jest postrzegany jako pewnego rodzaju zło, które wynika z nierozpoznania prawdy o człowieku i świecie bądź odejścia od niej, a co za tym idzie - od jedynych „właściwych” zasad moralnych. Pluralizm, jako zło, powinien być zwalczany (również przez rozwiązania prawne), życie społeczne zaś (a także jednostkowe) należy oprzeć na „właściwych" zasadach moralnych, do czego przyczyniać powinny się także działania aparatu państwa. Stanowisko takie charakterystyczne jest dla fundamentalizmu (w różnych jego odmianach) .

Po drugie, można wyróżnić również stanowisko tolerujące pluralizm (umiarkowanie negatywne w stosunku do pluralizmu). Pluralizm jest tutaj co prawda postrzegany jako zjawisko $\mathrm{w}$ pewnym stopniu negatywne, ale jest on tolerowany, jako pewien stan przejściowy (czy też pozorny) na drodze do uzyskania (bądź odzyskania) jedności. Pluralizm jest pewnym faktem kulturowym, ale nie celem kultury. Właściwym stanem kultury i społeczeństwa jest jedność oparta na obiektywnie właściwych zasadach (ewentualnie - na intersubiektywnych w ramach określonej wspólnoty kulturowej). Samego pluralizmu w zasadzie nie należy otwarcie zwalczać, należy jednak zabiegać, aby przynajmniej w kwestiach zasadniczych decyzji społecznych kierowano się wskazanymi, „obiektywnie właściwymi” wartościami. Wydaje się, że tego typu stanowisko odnaleźć można np. w radykalnej myśli komunitarystycznej, w ramach której „nawołuje” się do odnowienia, ożywienia ducha wspólnotowego i przeciwdziałania w ten sposób postępującej subiektywizacji wartości, jak również w niektórych nurtach myśli chrześcijańskiej, w ramach której do pewnego stopnia toleruje się pluralizm, jednak zabiega się, aby przynajmniej w kluczowych sprawach społecznych realizowano chrześcijański system wartości.

Po trzecie, można mówić o stanowisku wyraźnie aprobującym pluralizm (umiarkowanie pozytywnym w stosunku do pluralizmu). Pluralizm jest tutaj

${ }^{7}$ Na temat tego drugiego, a także jego związków z liberalizmem, zob. B. Polanowska-Sygulska, Pluralizm wartości i jego implikacje w filozofii prawa, Kraków 2008. Wydaje się, że należy starannie odróżniać pluralizm jako określony fakt społeczny od pluralizmu jako pewnego stanowiska filozoficznego.

${ }^{8}$ Przyjęta typologia nawiązuje w pewnym stopniu do zarysowanych przez A. Szahaja sześciu „strategii radzenia sobie z pluralizmem” (zob. idem, Jednostka czy wspólnota? Spór liberałów z komunitarystami a „sprawa polska”, Warszawa 2000, s. 106 i n.), jest jednak bardziej uproszczona i kładzie nacisk na nieco inne aspekty.

${ }^{9}$ Zob. ogólnie na temat fundamentalizmu w różnych jego odmianach W. Buksiński, Wspótczesne filozofie polityki, Poznań 2006, s. 167-190. 
postrzegany jako zjawisko do pewnego stopnia pozytywne i pożądane, aczkolwiek pożądana jest również poszerzająca się integracja społeczna oparta na konsensusie. Istnieje potrzeba, a przynajmniej możliwość, przezwyciężania pluralizmu i uzgadniania wartości $\mathrm{w}$ procesie racjonalnej argumentacji, co pozwala na ich konsensualną akceptację (istotną kategorią życia społecznego staje się właśnie konsensus). Tego typu stanowisko obecne jest przede wszystkim w poglądach Jürgena Habermasa, ale również w znacznym stopniu np. w poglądach Johna Rawlsa (niezależnie od istotnych różnic dzielacych obu autorów $\left.{ }^{10}\right)$.

Po czwarte, można mówić również o stanowisku zdecydowanie afirmującym pluralizm (zdecydowanie pozytywnym wobec pluralizmu). Pluralizm jest tutaj postrzegany jako zjawisko jednoznacznie pozytywne i pożądane. Można powiedzieć, że jest on traktowany jako pewna wartość samoistna, jako pewnego rodzaju bogactwo zasługujące na ochronę i powiększanie. Konkurencje i konflikty między różnymi formami życia, koncepcjami dobra, czy wartościami, postrzega się jako w pewnym sensie naturalne i stanowiące „żywioł” demokracji. Nie sposób wskazać jakiejś uniwersalnej miary, standardu pozwalającego na rozsądzenie sporów między konkurującymi opcjami. Aby jednak nie dochodziło do otwartej, uciekającej się do przemocy walki, konieczne jest zapewnienie pewnego modus vivendi, sposobu pokojowej koegzystencji różnych form życia (można w tym kontekście przywołać pogląd Johna Graya, że nie potrzebujemy wspólnych wartości, a jedynie wspólnych instytucji). Tego typu stanowisko obecne jest w poglądach wielu, skądinąd różniących się od siebie autorów, których łączy krytyczny stosunek do stanowiska trzeciego (umiarkowanie pozytywnego w stosunku do pluralizmu). Jako przykład można wskazać z jednej strony przede wszystkim liberalizm agonistyczny Johna Graya ${ }^{11}$, z drugiej zaś projekt demokracji radykalnej w wersji Ernesta Laclau i Chantal Mouffe ${ }^{12}$.

Po piąte, można także wyróżnić stanowisko niejako „fetyszyzujące” pluralizm (skrajnie pozytywne wobec pluralizmu). W takim ujęciu każda jedność jest forma przemocy, pluralizm zaś nigdy nie zostaje osiagnięty w dostatecznym stopniu. Kultura oraz wspólnota uniemożliwiają artykulację różnic, sa źródłem permanentnej przemocy, która wpisana jest w działanie każdej instytucji. W takim ujęciu wszelkie czynniki (np. państwo, czy też prawo) ograniczające w jakiśs sposób pluralizm są złem. Jak zauważa Andrzej Szahaj, stanowisko to jest raczej rzadkie w filozofii polityki i wiąże się ze skrajnymi wersjami poglądów postmodernistycznych ${ }^{13}$.

10 Zob. polemikę między tymi autorami: J. Habermas, Reconciliation through the Public Use of Reason: Remarks on John Rawl's Political Liberalism, „The Journal of Philosophy” 92, 1995, nr 3, s. 109-131; J. Rawls, Political Liberalism: Reply to Habermas, „The Journal of Philosophy” 92, 1995, nr 3, s. 132-180.

11 Zob. w szczególności, J. Gray, Dwie twarze liberalizmu, Warszawa 2001; idem, Po liberalizmie-eseje wybrane, Warszawa 2013.

12 Zob. w szczególności E. Laclau, Ch. Mouffe, Hegemonia i socjalistyczna strategia. Przyczynek do projektu radykalnej polityki demokratycznej, Wrocław 2007; Ch. Mouffe, Paradoks demokracji, Wrocław 2005.

${ }^{13}$ A. Szahaj, op. cit., s. 108. 
Jeżeli chodzi o niezwykle skrajne stanowisko - piąte - to nie będzie w dalszej części przedmiotem zainteresowania. Przyjęcie takiego stanowiska w jakiś sposób „unieważnia”, czyni bezprzedmiotowymi, wszystkie zagadnienia rozważane w niniejszym opracowaniu (w szczególności powoduje odrzucenie postulatu intersubiektywności czynności interpretacyjnych).

Jeżeli natomiast chodzi o również skrajne stanowisko pierwsze (1), to neguje ono w zasadzie współczesne regulacje konstytucyjne i demokrację, jest więc de facto wezwaniem do zmiany ustroju społeczno-politycznego. Niezależnie jednak od tego, z takim stanowiskiem dobrze koresponduje nominalistyczne ujęcie języka. W społeczeństwie i państwie urządzonym zgodnie z postulatami formułowanymi na gruncie tego stanowiska kontekst funkcjonalny przepisów prawnych jest tak dobrze określony, że wykładnia językowa (odwołanie się do reguł syntaktycznych i semantycznych systemu językowego) może nawet „przeszkadzać” w ustaleniu właściwego znaczenia tekstu prawnego. Na gruncie tego stanowiska sytuacja przypomina więc $\mathrm{w}$ istotnym stopniu sytuację opisanej na wstępie homogenicznej wspólnoty.

Jeżeli chodzi o stanowisko drugie (2), to należy zauważyć, że - mimo tolerowania różnorodności kontekstu funkcjonalnego - presuponuje się na jego gruncie posiadanie wiedzy (albo możliwość pozyskania tej wiedzy) na temat właściwego, „autentycznego” i jednorodnego kontekstu funkcjonalnego przepisów prawnych. Kontekst ten może nie być jeszcze do końca rozpoznany, jednak przez odpowiednie rozumowanie można ten kontekst „odkryć”.

$\mathrm{Na}$ gruncie tego stanowiska sytuacja przypomina więc również w pewnym stopniu sytuację opisanej na wstępie homogenicznej wspólnoty. Z takiego punktu widzenia wykładnia odwołująca się do syntaktycznych i semantycznych reguł systemu językowego nie jest bynajmniej potrzebna do zapewnienia intersubiektywności wyniku wykładni. Uwzględnienie „właściwego” kontekstu funkcjonalnego może z powodzeniem zapewnić intersubiektywność wykładni nawet bardzo niejasnych bądź wadliwie zredagowanych przepisów. Strukturalistyczne pojmowanie języka (i komunikacji za jego pomoca) staje się co najmniej niekonieczne (jeżeli nie zbędne). Z kolei nominalistyczna wizja języka dobrze współgra $\mathrm{z}$ takim stanowiskiem, syntaktyczno-semantyczne struktury języka nie stanowią bowiem tutaj żadnego „oporu” wobec wykładni zgodnej z właściwym kontekstem funkcjonalnym. Kontekst pragmatyczny (funkcjonalny) jest dobrze określony i zapewnia efektywną komunikację oraz sprawiedliwe rozstrzygnięcia.

Z kolei przy przyjęciu stanowisk (3) i (4) do realizacji postulatu intersubiektywności potrzebna jest strukturalistyczna wizja języka. Ponieważ akceptuje się znaczny stopień nieokreśloności kontekstu funkcjonalnego i trudności z jego „ujednoznacznieniem”, odwołanie się do syntaktyczno-semantycznych reguł systemu językowego pozwala zwiększyć intersubiektywność wyniku wykładni. Jest to możliwe, odwołanie się do tych reguł pełni bowiem rolę ograniczająca przy interpretacji, eliminuje z góry wiele możliwości dopuszczalnych w świetle pluralistycznego kontekstu funkcjonalnego (kontekstu pragmatycznego).

Pozostaje oczywiście trudne zagadnienie sposobu dookreślenia, ujednolicenia pluralistycznego kontekstu funkcjonalnego tak, aby umożliwił jakiśs 
wybór między wariantami interpretacyjnymi, które wciąż pozostają dopuszczalne w świetle reguł syntaktycznych i semantycznych systemu językowego. Niemniej jednak strukturalistyczna wizja języka jest niezbędna na gruncie stanowisk trzeciego (3) i czwartego (4) - oczywiście przy założeniu, że chce się zachować postulat intersubiektywności wyniku wykładni.

Należy w tym miejscu zauważyć, że pewne wątpliwości mogą być związane z tym, czy powyższe uwagi w pełni stosują się do stanowiska trzeciego (3), w szczególności do pewnej jego wersji odwołującej się do argumentacyjnej wizji prawa. Można bowiem uznać, że pluralistyczny kontekst funkcjonalny może zostać zawsze odpowiednio ujednolicony w drodze dyskursu przeprowadzonego z zachowaniem określonych wymogów. Dyskurs taki pozwala bowiem na uniwersalizację określonych rozstrzygnięć aksjologicznych. Można więc uznać, że dyskurs taki może zastapić odwołanie się do syntaktyczno-semantycznych struktur systemu językowego.

Trzeba jednak w tym miejscu zauważyć, że wymagać by to musiało w zasadzie powtórzenia, w odniesieniu do określonego zagadnienia wymagającego rozstrzygnięcia, dyskursu politycznego czy też moralnego. Wtedy jednak pod znakiem zapytania staje byt prawa. Sam Habermas zauważa problemy z tym związane, krytykując nieprzywiązywanie dostatecznej wagi do różnicy między wartościami a normami. Wskazuje on, że ważenie zasad pozbawia konstytucyjne prawa normatywności i czyni je celami, wartościami czy też wymogami polityki, wskutek czego zapora wzniesiona w dyskursie prawniczym przez deontologiczne rozumienie norm prawnych ulega zniszczeniu ${ }^{14}$. Ponadto warto dodać, że jednym z zasadniczych środków pozwalających dyskursowi prawniczemu osiagnąć wyższy stopnień konkluzywności w stosunku do innych dyskursów jest właśnie waga argumentu ,językowego”.

V. Przyjęcie postulatu intersubiektywności czynności interpretacyjnych i ich wyników pozwala stwierdzić, że istnieje zależność między założeniem na potrzeby wykładni prawa określonej wizji języka a określonym stosunkiem do faktu pluralizmu wartości (i na odwrót). Zależność ta nie polega oczywiście na jakiejśs ścisłej determinacji wyboru wizji języka przez przyjęcie określonego stosunku do faktu pluralizmu wartości (czy też odwrotnie). Chodzi jednak o to, że - ogólnie rzecz ujmując - przyjęcie nominalistycznej wizji języka jest łatwiejsze do pogodzenia z negatywnymi stanowiskami w odniesieniu do faktu pluralizmu wartości, przyjęcie wizji strukturalistycznej zaś łatwiejsze jest do pogodzenia ze stanowiskami pozytywnymi. Przyjęcie wizji nominalistycznej zakłada uznanie ogromnego stopnia niezdeterminowania wykładni prawa (i interpretacji w ogóle) ze strony „fikcji”, jaka jest system językowy, dlatego też podstawy intersubiektywności wyniku wykładni trzeba poszukiwać gdzie indziej. Dogodna tego rodzaju podstawą może być w szczególności idea jednego powszechnie podzielanego systemu wartości.

Z kolei przyjęcie wizji strukturalistycznej skutkuje oparciem intersubiektywności wykładni przede wszystkim na systemie językowym, co powoduje, że

14 J. Habermas, Faktyczność i obowiazywanie. Teoria dyskursu wobec zagadnień prawa $i$ demokratycznego państwa prawnego, Warszawa 2005, s. 273-276. 
łatwiej zaakceptować fakt braku jednego powszechnie podzielanego systemu wartości. Można by powiedzieć, że im bardziej będziemy chcieli odchodzić od związania interpretatora systemem językowym, tym bardziej będziemy potrzebować „powszechnie podzielanego systemu wartości” (oczywiście przy przyjęciu postulatu intersubiektywności wyniku wykładni). Jeszcze innymi słowy, można tę myśl wyrazić lapidarnie w sposób następujący: możemy odrzucić ideę systemu językowego albo możemy odrzucić ideę jednego systemu wartości, jeżeli jednak zechcemy jednocześnie konsekwentnie odrzucić i jedno, i drugie, to nie pozostanie nic (ewentualnie - prawie nic), na czym moglibyśmy oprzeć intersubiektywność wykładni. Nie znaczy to oczywiście, że nie można w ramach określonej teorii czy koncepcji wykładni prawa łączyć wizji nominalistycznej z pozytywnym stosunkiem do pluralizmu wartości, w takim przypadku jednak bardzo wymagajacym filozoficznie i teoretycznie zadaniem jest udzielenie odpowiedzi na pytanie o podstawę intersubiektywności wyników wykładni. Pewnym rozwiązaniem jest odwołanie się do procedury „wynegocjowywania" wyników w tak czy inaczej zorganizowanym dyskursie. Każda jednak procedura musi odwoływać się do czegoś „materialnego”, co z kolei generuje dalsze problemy.

VI. Na zakończenie niniejszego opracowania warto wskazać na określone rozwiązania z zakresu teorii wykładni dotyczące relacji między wykładnia językową a pozajęzykową (w szczególności funkcjonalna) oraz ich związki ze strukturalizmem bądź nominalizmem.

Należy wskazać na trzy modele rozwiązania zagadnienia chronologicznej relacji wykładni językowej do pozajęzykowej. Zgodnie z modelem pierwszeństwa chronologicznego wykładni językowej w pierwszej kolejności należy przeprowadzić wykładnię językową (odwołać się do semantycznych i syntaktycznych reguł języka), a w dalszej kolejności dopiero wykładnię pozajęzykową. Wydaje się, że można wyróżnić również „model irrelewacji chronologicznej” (w ramach którego wykładnia pozajęzykowa dokonywana jest niezależnie od językowej i nie ma w związku z tym znaczenia kolejność ich dokonywania, na dalszym natomiast etapie dokonuje się między nimi wyboru), a także „model pierwszeństwa chronologicznego wykładni pozajęzykowej”, który zakłada pierwszeństwo dokonywania wykładni pozajęzykowej, w szczególności funkcjonalnej $^{15}$. Można powiedzieć, że pierwszy model koresponduje ze strukturalistycznym pojmowaniem języka, dwa kolejne modele zaś (a w szczególności ten ostatni) korespondują z nominalistycznym pojmowaniem języka.

Warto w tym miejscu przywołać również wskazaną przez Marka Smolaka typologię ujęć kwestii pierwszeństwa wagi wykładni językowej w relacji do wykładni funkcjonalnej (choć autor wyraźnie tego nie wskazuje, wydaje się,

\footnotetext{
15 Trudno w tym miejscu wskazać przykłady koncepcji mieszczących się w ramach dwóch ostatnich ujęć, dlatego że z reguły nie odróżnia się właściwie chronologii stosowania dyrektyw interpretacyjnych od ich wagi. O odróżnieniu chronologii od wagi zob. O. Bogucki, M. Zieliński, Wykładnia prawa we wspótczesnym orzecznictwie Trybunału Konstytucyjnego, Sadu Najwyższego i Naczelnego Sadu Administracyjnego, w: L. Gardocki et al. (red.), Orzecznictwo sqdowe w sprawach karnych. Aspekty europejskie i unijne, Warszawa 2008, s. 79.
} 
że chodzi właśnie o wagę, a nie kolejność) ${ }^{16}$. Wyróżnia on: podejście heteronomiczne, podejście holistyczne oraz podejście autonomiczne. Podejście heteronomiczne uznaje pierwszeństwo wagi jednoznacznej wykładni językowej (poza pewnymi wyjątkami). Podejście holistyczne charakteryzuje z kolei brak określenia reguł preferencji. Nie wiąże się z wykładnią językową priorytetu, uznając, że wszystkie typy dyrektywy mają ten sam status. Głównymi przedstawicielami holizmu, zdaniem Marka Smolaka, sa William Eskridge i Philip Frickey ${ }^{17}$. Z kolei podejście autonomiczne charakteryzuje się preferowaniem wykładni funkcjonalnej przed językowa. Jako przedstawiciela podejścia autonomicznego Marek Smolak wskazuje m.in. Karla Klare'a ${ }^{18}$. Wydaje się, że zarówno podejście holistyczne, jak i autonomiczne mieszczą się w ramach nominalistycznego pojmowania języka (choć podejście holistyczne w mniejszym stopniu, przyjmuje bowiem pierwszeństwo chronologiczne wykładni językowej). Warto jeszcze w tym kontekście dodać, że Smolak trafnie wskazuje na zasadniczą słabość podejścia holistycznego: nie mówi ono nic na temat preferencji między rozbieżnymi rezultatami zastosowania różnych dyrektyw interpretacyjnych ${ }^{19}$.

Na zakończenie niniejszego opracowania warto wskazać, jakie stanowisko we wskazanych wyżej kwestiach przyjmuje derywacyjna koncepcja wykładni jako wiodąca obecnie w polskiej literaturze koncepcja normatywna, która stanowi jeden z głównych składników polskiej zintegrowanej koncepcji wykładni ${ }^{20}$.

Przede wszystkim na gruncie koncepcji derywacyjnej przez wykładnię językową rozumie się odwołanie do reguł składniowych i znaczeniowych języka, w którym formułowane są teksty prawne (chodzi tu o język powszechny nie zaś potoczny ${ }^{21}$ ). W aspekcie chronologicznym wykładnia językowa dokonywana jest w pierwszej kolejności ${ }^{22}$. Po dokonaniu wykładni językowej należy w każdym przypadku dokonać wykładni funkcjonalnej ${ }^{23}$. Jeżeli odwołanie się do dyrektyw językowych nie pozwala na wskazanie jednego znaczenia interpretowanego wyrażenia, wykładnia funkcjonalna służy dokonaniu wyboru jednego z nich jako właściwego. Jeżeli odwołanie się do reguł składniowych i znacze-

${ }^{16}$ M. Smolak, Wykładnia celowościowa $z$ perspektywy pragmatycznej, Warszawa 2012, s. $55-61$.

${ }^{17}$ Ibidem, s. 59 i cyt. tam literatura. W polskiej literaturze zwolennikiem holizmu jest M. Matczak, zob. idem, Summa iniuria. O błędzie formalizmu w stosowaniu prawa, Warszawa 2007.

${ }_{18}$ M. Smolak, op. cit., s. 61 i cyt. tam literatura.

${ }^{19}$ Ibidem.

${ }^{20} \mathrm{Na}$ temat integracji koncepcji wykładni zob. M. Zieliński et al., Zintegrowanie polskich koncepcji wyktadni prawa, „Ruch Prawniczy, Ekonomiczny i Socjologiczny” 2009, z. 4, s. 23 i n.; M. Zieliński, M. Zirk-Sadowski, Klaryfikacyjność $i$ derywacyjność $w$ integrowaniu polskich teorii prawa, „Ruch Prawniczy, Ekonomiczny i Socjologiczny” 2011, z. 2, s. 102 i n.

${ }^{21}$ Zob. na ten temat A. Chodun, Język prawny a język potoczny, w: E. Malinowska (red.), Język, prawo, spoteczeństwo, Opole 2004, s. 77 i n.; eadem, Leksyka tekstów aktów prawnych, „Ruch Prawniczy, Ekonomiczny i Socjologiczny” 2006, nr 4, s. 19 i n.; eadem, Stownictwo tekstów prawnych w zasobie leksykalnym wspótczesnej polszczyzny, Warszawa 2007. Zob. również charakterystykę języka prawnego z perspektywy socjolingwistyki zawartą w: T. Gizbert-Studnicki, Język prawny $z$ perspektywy socjolingwistycznej, „Zeszyty Naukowe Uniwersytetu Jagiellońskiego. Prace z Nauk Politycznych” 1986, nr 26.

${ }^{22}$ M. Zieliński, op. cit., s. 236.

${ }^{23}$ Ibidem, s. 237-238. 
niowych wskazuje na określone jedno znaczenie interpretowanego wyrażenia, to wykładnia funkcjonalna może albo potwierdzić to znaczenie jako właściwe, albo też - ale tylko w określonych sytuacjach - może być podstawą do odrzucenia tego znaczenia i przyjęcia innego znaczenia ${ }^{24}$. Rozwiąania takie korespondują ze strukturalistycznym ujęciem języka (na marginesie warto dodać, że są one również w zasadniczej mierze zgodne z praktyką interpretacyjna najwyższych organów władzy sądowniczej ${ }^{25}$ ). Można więc powiedzieć, że filozoficznymi założeniami przyjętych w koncepcji derywacyjnej (a także koncepcji zintegrowanej) dyrektyw odnoszacych się do relacji między wykładnia językową i pozajęzykową są wzięte łącznie: strukturalistyczna wizja języka (i komunikacji za jego pomoca), stanowisko aprobujace albo stanowisko afirmujące pluralizm, a także oczywiście postulat intersubiektywności czynności interpretacyjnych i ich wyników.

dr Olgierd Bogucki

Uniwersytet Szczeciński

booca@mec.univ.szczecin.pl

\section{THEORIES OF LANGUAGE, VALUE PLURALISM AND THE THEORY OF LEGAL INTERPRETATION}

\section{Sum mary}

This article explores relations between philosophical ideas of the language and the attitude to the pluralism of values in the context of legal interpretation. It argues that if the postulate of intersubjectivity in legal interpretation is to be maintained, the nominalist idea of language will be more coherent with the negative attitude to value pluralism, while the structural idea is more coherent with the positive one. The intersubjectivity of legal interpretation can be based on a language system or on a system of values. If the idea of a language system were to be removed (as nominalists propose), the idea of one clear system of values will be needed, while where the idea of one system of values were to be maintained, then an idea of a language system will be necessary.

${ }^{24}$ Ibidem, s. 238 i n.

${ }^{25}$ Zob. na ten temat np. O. Bogucki, Wykładnia funkcjonalna $w$ działalności najwyższych organów władzy sqdowniczej, Szczecin 2011, s. 283 i n. 
Copyright of Journal of Law, Economics and Sociology is the property of Faculty of Law and Administration of Adam Mickiewicz University in Poznan and its content may not be copied or emailed to multiple sites or posted to a listserv without the copyright holder's express written permission. However, users may print, download, or email articles for individual use.

Właścicielem praw autorskich do „Ruchu Prawniczego, Ekonomicznego i Socjologicznego” jest Wydział Prawa i Administracji Uniwersytetu im. Adama Mickiewicza w Poznaniu. Zawartość czasopisma nie może być kopiowana, przesyłana do innych stron internetowych bądź zamieszczana na blogach bez pisemnej zgody wydawcy. Niemniej artykuły można drukować, kopiować lub przesyłać w formie elektronicznej na własny użytek. 